\title{
Effect of Intercropping Wheat with Sugar Beet Patterens under Mineral Nitrogen and Bio-Organic Fertilization
}

\author{
El-Seidy, E. $\mathrm{H}^{1}$, A. M. Sheha ${ }^{2}$, Ola A. Saleh ${ }^{2 *}$, E. A. Rashwan ${ }^{1}$ \\ ${ }^{1}$ Agronomy Department, Faculty of Agriculture, Tanta University, El-Gaish, Tanta Qism 2, Tanta, Gharbia Governorate, \\ Egypt \\ ${ }^{2}$ Field Crops Research Institute, A. R. C, Egypt
}

*Corresponding Author

Ola A. Saleh

\author{
Article History \\ Received: 22.08 .2021 \\ Accepted: 30.09 .2021 \\ Published: 28.02.2022
}

\begin{abstract}
Two field experiment were conducted at EL-Gemiza Agricultural Research station El- Gharbia Governorate, during 2016/17 and 2017/18 seasons to study the effect of three sowing dates $\left(15^{\text {th }}\right.$ October, $1^{\text {st }}$ November and $15^{\text {th }}$ November) and six intercropping sowing rate of faba bean (Vicia faba) cv. Giza 843 with sugar beet (Beta vulgaris L.) cv. Halawa kws. In all intercropping systems (IS) sugar beet was 35000 plant/fad (sugar beet sown one side of bed $120 \mathrm{~cm}$ width with 1 seed/hill and $20 \mathrm{~cm}$ hill space) while, faba bean densities differ under all intercropping systems as follows, $\mathrm{IS}_{1}\{70000$ faba bean plant/fad (sown one row on the top of sugar beet ridges with two seeds/hill and $10 \mathrm{~cm}$ hill space) $\}, I_{2}\{70000$ faba bean plant/fad (sown two rows on the top of sugar beet bed and the bed with one seed/hill and $10 \mathrm{~cm}$ hill space $)\}, \mathrm{IS}_{3}\{(35000$ faba bean plants /fad. Sown one row on the top of sugar beet bed with two seeds/hill and $20 \mathrm{~cm}$ hill space) $\}, \mathrm{IS}_{4}\{35000$ faba bean plant/fad (sown two rows on the top of sugar beet ridges with one seed/hill and $20 \mathrm{~cm}$ hill space) $\}, \operatorname{IS}_{5}\{17500$ faba bean plant/fad (sown one row on the top of sugar beet ridges with two seeds/hill and $40 \mathrm{~cm}$ hill space) $\}$ and IS $_{6}\{17500$ faba bean plant/fad (sown two rows on the top of sugar beet ridges with one seeds/hill and $40 \mathrm{~cm}$ hill space) $\}$.
\end{abstract}

Keywords: (Vicia faba), crops, agricultural practice, sugar production.

\section{INTRODUCTION}

Intercropping involves cultivating two or more crops in a field simultaneously, and is mainly practiced in regions where soils are relatively degraded. Intercropping is receiving increasing global interest as an agricultural practice as farmers strive to be more sustainable and maintain soil health (Glaze-Corcoran et al., 2020). Crops selected for intercropping normally have different abilities to use the resources available for growth, which leads to yield advantages and increased stability compared to a single crop in a low input system (Corre-Hellou et al., 2011). An agronomic advantage has been demonstrated of intercropping sugar beet with other winter crops like wheat (Badr 2013 and 2017).

Sugar beet is one of the most important sources of sugar worldwide. It plays a prominent role for sugar production, about $40 \%$ of sugar in the world is normally produced from sugar beet. The mean of sugar beet production was 4987.03 thousand ton, whereas the mean of sugar beet cultivated area is 99.60 thousand hectare (Elasraag 2019). The world average consumption per person is about $10-15 \mathrm{~kg}$ of sugar per year but in Egypt reaches $43 \mathrm{~kg}$ of sugar/person/year (El-Sherief 2013). This creats a big jab between production and consumption.

Wheat is a strategic crop all over the world. Egyptian total production of wheat hardly satisfies about $35 \%$ of consumption and its cultivated area in Egypt was about 2.9- 3.0 million fadden in 2018/19 season and hited 3.4 million fadden in $2019 / 2020^{(*)}$ but on along term through the last decades this cultivated area suffered from high competition with the other winter crops, especially berseem clover (Ghoneim 2021). So, the national target in Egypt aimed to increase

${ }^{(*)}$ Agricultural Statistics, Economic Affairs Sector. Ministry of Agric. And Reclamination, Egypt.

Copyright $(2022$ The Author(s): This is an open-access article distributed under the terms of the Creative Commons Attribution 4.0 International License (CC BY-NC 4.0) which permits unrestricted use, distribution, and reproduction in any medium for noncommercial use provided the original author and source are credited. 
wheat productivity to save the human need and fill the gap between the local consumption and production, through several ways, one of these is intercropping wheat with sugarbeet as an agricultural paractice to maximize productivity of both crops and allow full utilization of environmental resources with minimum competition (Badr 2017).

Intuitively, under intensive and consecutive cropping conditions the essential nutrient elements such as nitrogen will be insufficient in the soil. Nitrogen is considered the most important nutrient and ranked the second limiting factor in the crop production and limits yield in fertilized agriculture. It is applied in order to increase yield and improve crop quality. Also, it contributes significantly to protein content, chlorophyl, nucleic acid and many plant substances (Saifullah et al., 2002). This insufficient levels of nitrogen under intercropping systems could be compensated by adding nitrogen whether in its mineral, organic and bio forms. Many researchers studied the effect of mineral, organic and bio nitrogen on wheat and sugar beet as sole crops but very limited available information about application of these different forms of nitrogen on intercropped sugar beet with wheat.

Therefore, the specific objective of this research was to study different intercropping patterns between sugar beet and wheat under different mineral nitrogen rates and bio-organic nitrogen sources and determine its effects on yield, yield components and the productivity of these crops and farmers benefits.

\section{Materials ANd Methods}

Two field experiments were conducted at El-Gemmeiza Agricultural Research Station, Agriculture Research Center (ARC), Egypt, during the two successive winter seasons 2017/18 and 2018/19. Study different intercropping patterns of wheat (Triticum aestivum, L.) cv. Sakha 94 with sugar beet (Beta Vulgaris, 1.) cv. Shantala kws (multigerm) under different mineral nitrogen rates and bio-organic nitrogen sources and determine its effects on yield, yield components and the productivity of these crops and farmers benefits was the main objective of this research. The preceding summer crop was corn (Zea mays L.) in both seasons.

Representative soil samples were taken from each site at the depth of $0-15 \mathrm{~cm}$ and $0-30 \mathrm{~cm}$ from the soil surface. Samples were air-dried then ground to pass through a two mm sieve and well mixed. Mechanical and chemical analysis of soil was determined in Soil Research Institute, ARC, according to Jackson, 1967 (Table 1).

A split-split plot design with three replications was used for each experiment. The main plots were assigned to intercropping patterns and the sub-plot to mineral nitrogen rates, whereas the bio-organic nitrogen fertilizers were arranged in the sup-sup plot as follows:

\section{A. Intercropping patterns (P) (main plots):}

1. Intercropping wheat with sugar beet $(100 \%$ of the recommended seed rate of sugar beet $+20 \%$ of the recommended seed rate of wheat).

2. Intercropping wheat with sugar beet $(100 \%$ of the recommended seed rate of sugar beet $+30 \%$ of the recommended seed rate of wheat).

3. Intercropping wheat with sugar beet $(100 \%$ of the recommended seed rate of sugar beet $+40 \%$ of the recommended seed rate of wheat).

4. For the above mentioned three intercropping patterns, sugar beet was sown in hills $20 \mathrm{~cm}$ apart on two sides of 120 $\mathrm{cm}$ terrace, whereas the wheat seeds were sown on the terrace surface with seeding rate according to each intercropping pattern

5. Pure-stand of sugar beet was sown in hills $20 \mathrm{~cm}$ apart on one side of $60 \mathrm{~cm}$ ridges to achieve the recommended plant density (35.000 plants per faddan after thinning).

6. Pure-stand of wheat was sown with its recommended seeding rate (50 Kg seeds/ faddan) on the surface of $120 \mathrm{~cm}$ terraces.

\section{B. Mineral nitrogen levels (N) (sub plots)}

1. Sixteen (60) Mineral Nitrogen units per faddan

2. Eighteen (80) Mineral Nitrogen units per faddan (the recommended rate for sugar beet)

3. Hundred (100) Mineral Nitrogen units per faddan

\section{Bio-organic nitrogen fertilizers (O) (sub-sub plots)}

1. Serialine: A nitrogen bio-fertilizer Serialine which is a mixture of two different nitrogen fixers of the genera Azotobacter and Azosprillium was added at the rate of $1 \mathrm{Kg}$ (two packets) per faddan on both kinds of seeds before sowing directly.

2. Compost: An organic nitrogen fertilizer (Rice straw compost) was added at the rate of 5 tons per faddan during soil preparation.

3. Mixture of Serialine and Compost was added at the rate of $1 \mathrm{Kg}$ (two packets) per faddan for Serialine and 5 tons per 
faddan for Compost.

Table 1: Some chemical properties of the used rice straw compost

\begin{tabular}{|c|c|}
\hline Properties & Compost, $\mathrm{C}$ \\
\hline Density $\left(\mathrm{g} \mathrm{cm}^{-3}\right)$ & 0.57 \\
\hline pH (1 :10 manure: water) & 7.43 \\
\hline $\mathrm{EC}, \mathrm{dS} \mathrm{m}^{-1}(1: 10$ manure: water $)$ & 3.15 \\
\hline $\mathrm{Ca}, \%$ & $\mathbf{0 . 8 2}$ \\
\hline Mg, \% & 0.25 \\
\hline $\mathrm{Na}, \%$ & 0.23 \\
\hline Available Fe, ppm & 1197 \\
\hline Available Zn, ppm & 79.68 \\
\hline Available Mn, ppm & 64.18 \\
\hline Available $\mathrm{Cu}, \mathrm{ppm}$ & 28.92 \\
\hline Ash, \% & 62.46 \\
\hline Organic matter, $\%$ & 32.34 \\
\hline Organic Carbon, \% & 18.76 \\
\hline Total N, \% & 1.54 \\
\hline $\mathrm{C} / \mathrm{N}$ ratio & 12.18 \\
\hline Total P, \% & $\mathbf{0 . 8 6}$ \\
\hline Total K, \% & 2.11 \\
\hline
\end{tabular}

Table 2: The analysis of the Serialine biofertilizer according to (Rashwan et al., 2015)

\begin{tabular}{|c|c|c|c|c|c|}
\hline \multicolumn{2}{|c|}{ Using a Sumigraph NC analyzer } & \multicolumn{4}{|c|}{ Using phospholipid fatty acids (PLFAs) analysis } \\
\hline \multirow[t]{2}{*}{$\begin{array}{l}\text { Total Nitrogen } \\
\text { percentage }\end{array}$} & \multirow[t]{2}{*}{$\begin{array}{l}\text { Total Carbon } \\
\text { percentage }\end{array}$} & $\begin{array}{l}\text { Bacterial } \\
\text { PLFAs }\end{array}$ & $\begin{array}{l}\text { Fungal } \\
\text { PLFAs }\end{array}$ & $\begin{array}{l}\text { Actinomycetes } \\
\text { PLFAs }\end{array}$ & $\begin{array}{l}\text { Arbuscular } \\
\text { mycorrhizal PLFAs }\end{array}$ \\
\hline & & \multicolumn{4}{|c|}{ Microgram per gram dry soil ( $\mu \mathrm{g} / \mathrm{gm}$ dry soil) } \\
\hline $0.1252601 \%$ & $4.506026 \%$ & 16.903 & 3.536 & 0.931 & 0.487 \\
\hline
\end{tabular}

The plot size was $18 \mathrm{~m}^{2}$, included 10 ridges $60 \mathrm{~cm}$ apart or 5 terrace $120 \mathrm{~cm}$ apart and $3 \mathrm{~m}$ long. Sowing of sugar beet took place on October $10^{\text {th }}$ and $14^{\text {th }}$ in 2017 and 2018 seasons, respectively. Seeds of multigerm sugar beet cultivar "Shantala kws" were sown in hills on the two sides of $120 \mathrm{~cm}$ terrace at the rate of 3-4 seed balls per hill. Thirty five days after sowing, thinning to one plant per hill was done. Then seeds of wheat were broadcasted on the surface of terraces on $15^{\text {th }}$ and $18^{\text {th }}$ November in 2017 and 2018 seasons, respectively. Sugar beet plants in all plots were fertilized by side-dressing one-half of the target nitrogen rate (based on each treatment) in the form of urea (46\% N) and irrigated immediately, while the other half was added just before the second irrigation. Regarding to the other macro-elements nutrients, the experimental field was fertilized with $31 \mathrm{~kg} \mathrm{P}_{2} \mathrm{O}_{5}$ per faddan in the form of superphosphate fertilizer (15.5 $\left.\% \mathrm{P}_{2} \mathrm{O}_{5}\right)$ and $24 \mathrm{~kg} \mathrm{~K} 2 \mathrm{O}$ per faddan in the form of potassium sulphate $\left(48 \% \mathrm{~K}_{2} \mathrm{O}\right)$ during soil preparation.

All other practices were applied as recommended for each crop in the region. Harvest of sugar beet plants were conducted on May $7^{\text {th }}$ and $5^{\text {th }}$ in 2018 and 2019 seasons, respectively. While, the harvest of wheat plants were on May $9^{\text {th }}$ and $7^{\text {th }}$ in 2018 and 2019 seasons, respectively

\section{RESUlTS AND DisCUSSION:}

\section{Wheat:}

\section{A. Growth measurmets}

II. A. A. Effect of intercropping patterens (P)

II. A. A. 1. Plant height (cm)

Means of plant height $(\mathrm{cm})$ as affected by intercropping patterns between sugar beet and wheat and their interaction in 2017/18 and 2018/19 seasons are presented in Table 1.

The investigated intercropping patterens had a significant effect on plant height in both seasons. The tallest plants were found in solid plants in both seasons, followed by the third intercropping patteren (100\% of the recommended seed rate of sugar beet $+40 \%$ of the recommended seed rate of wheat) which ranked the first among investigated patterens and recorded the tallest plants compared to other patterens, followed by the second intercropping patteren $(100 \%$ of the recommended seed rate of sugar beet $+30 \%$ of the recommended seed rate of wheat) which came in the intermediate, whereas the shortest plants were recorded by the first patteren $(100 \%$ of the recommended seed rate of sugar beet $+20 \%$ of the recommended seed rate of wheat), in both seasons. 
This increase in plant height may be due to the inter and intra plants competition under dense planting caused a reduction in light intensity within plant canopy which encourage IAA (indole acetic acid) synthesis in stem tissues, hence, an increase in cell division and elongation would be expected. These results are in harmony with those obtained by El-Moghazy (2013) and Badr (2017) where they obtained the tallest plants of wheat from pure stand folllowed by the highest wheat plants denisity patteren and the shortest plants were observed under the lowest wheat plants denisity patteren

\section{A. A. 2. Flag leaf area $\left(\mathrm{cm}^{2}\right)$}

Data in Table 2 indicated that flag leaf area at milk ripe stage was significantly affected by intercropping patterns.

The highest flag leaf area at milk ripe stage of wheat were scored by solid (pure stand) plants in both seasons. On the level of intercropping patterens, the second intercropping patteren (100\% of the recommended seed rate of sugar beet $+30 \%$ of the recommended seed rate of wheat) ranked the first, followed by the first patteren $(100 \%$ of the recommended seed rate of sugar beet $+20 \%$ of the recommended seed rate of wheat), while the third intercropping patteren $(100 \%$ of the recommended seed rate of sugar beet $+40 \%$ of the recommended seed rate of wheat) ranked the last for this trait, in both seasons.

Increasing seed rate of wheat from 20 to $30 \%$ of the recommended increased flag leaf area which may be due to the decrease in number of tillers for each plant which means less number of flag leaves for each plant. On the other hand, increasing seed rate of wheat from 30 to $40 \%$ of the recommended reduced flag leaf area due to dense sowing which resulting in severe competition among wheat plants as well as between sugar beet and wheat plants for nutrients, water and light. Similar results were obtained by Dalia EL Hag (2012) and Badr (2017).

\section{A. B. Effect of Mineral nitrogen levels (N) \\ II. A. B. 1. Plant height (cm)}

Data in Table 2 cleared that plant height $(\mathrm{cm})$ at milk-ripe stage for wheat plants intercropped with sugar beet increased significantly by increasing nitrogen fertilizer levels/fed. The N3 level (100 kg N/fed.) recorded the tallest plants whereas the shortest plants were scored by the $\mathrm{N} 1$ level $(60 \mathrm{~kg} \mathrm{~N} / \mathrm{fed}$.), this increase in plant height by raising nitrogen levels refer to the role of nitrogen in enhances meristmatic activity, stimulation of cell division and internode elongation. Similar results obtained by Dalia EL-Hag (2012), Badr (2017) and Maqsood et al., (2019).

\section{A. B. 2. Flag leaf area $\left(\mathrm{cm}^{2}\right)$}

Nitrogen fertilizer levels had a significant effect on flag leaf area at milk-ripe stage for wheat plants intercropped with sugar beet in both seasons. The results indicated that, increasing nitrogen fertilizer levels from 60 to $100 \mathrm{~kg} \mathrm{~N} /$ fed. increased flag leaf area Table 1, the highest nitrogen fertilizer levels $100 \mathrm{~kg} \mathrm{~N} /$ fed. recorded the highest leaf area. On contrast, the lowest nitrogen fertilizer levels $60 \mathrm{~kg}$ N/fed. recorded the lowest leaf area $\left(\mathrm{cm}^{2}\right)$ in both seasons. Increase in nitrogen application favorably affected flag leaf area due to the role of nitrogen as the most nutritive elements needed for the vegetative growth of cereals. These results are in accordance with those obtained by Badr (2017) and Olga et al., (2019).

\section{A. C. Effect of bio-organic nitrogen fertilizers (O)}

II. A. C. 1. Plant height (cm)

Values of plant height as affected by bio-organic nitrogen fertilizers in 2017/18 and 2018/19 seasons are presented in Table 2. It is obvious that, the tallest plants were scored by the application of mixture (Ser.+comp.) followed by the application of compost only, whereas, the application of serialine only recorded the shortest plants, in both seasons. This trend of data may be due to the nitrogen availability caused by the mixed application of organic fertilization contains high percent of organic matter as a long term source of nitrogen side by side with $\mathrm{N}_{2}$ fixing bacteria in serialine biofertilizer. This positive effect of the mixture of bio-organic fertilizer is a clear argument for the essential role of nitrogen for enhancing meristmatic activity, stimulation of cell division and internode elongation. Results here are in accordance with those reported by Mohammed et al., (2012) and Gomaa et al., (2015) where they found a significant incerement in plant height as a result for adding organic fertilizer to wheat. Also, Rashwan et al., (2019), found that, the wheat plants under application of biofertilizers were taller than it's under control (untreated) treatments.

Worthy to mention that, solid (pure stand) plants scored the heighst plant height in both seasons compared to the intercropped plants as a result to the high level of competition among solid plants and the full applied recommended nitrogen dose provided to solid plants. 


\section{A. C. 2. Flag leaf area $\left(\mathrm{cm}^{2}\right)$}

Concerning to flag leaf area at milk-ripe stage for wheat plants intercropped with sugar beet in both seasons as affected by bio-organic nitrogen fertilizers, the results indicated that, application of mixture (Ser.+comp.) recorded the highest flag leaf area in both seasons with insignificant difference with application of compost only in the first season, whereas, the application of serialine only recorded the lowest flag leaf area in both seasons. On the other hand, solid (pure stand) plants surpassed the intercropped plants concerning to flag leaf area.

Mixture application of (Ser.+comp.) cause incerements in nitrogen, other macro and micro elements and growth supstances, which encourging photosynthesis and other essential metabolic activities which affect positively on vegetative growth and development. These results are in accordance with those obtained by Gomaa et al., (2015) where they found a significant incerement in flag leaf area as a result for adding organic fertilizer to wheat. Also, Rashwan et al., (2019), found that, biofertilizers application increased significantly flag leaf area of wheat plants.

\section{A. D. Effect of Interactions (I)}

II. A. D. 1. Plant height (cm)

The data presented in Table 1 revealed that the interaction between between intercropping patterens and mineral nitrogen fertilization levels had a significant effect on plant height. However, the nitrogen fertilization level (100 kg $\mathrm{N} /$ fed.) under the intercropping patteren $(100 \%$ of the recommended seed rate of sugar beet $+40 \%$ of the recommended seed rate of wheat) recorded the tallest plants, in both seasons.

The data presented in Table 2 revealed that the interaction between the interaction between intercropping patterens and bio-organic nitrogen fertilizers had a significant effect on plant height in the first season only. However, application of mixture (Ser.+comp.) under the intercropping patteren (100\% of the recommended seed rate of sugar beet $+40 \%$ of the recommended seed rate of wheat) recorded the highest values of the trait in view.

\section{A. D. 2. Flag leaf area $\left(\mathrm{cm}^{2}\right)$}

The data presented in Table 1 revealed that the interaction between between intercropping patterens and mineral nitrogen fertilization levels had a significant effect on flag leaf area. However, the nitrogen fertilization levels (80 and $100 \mathrm{~kg} \mathrm{~N} / \mathrm{fed}$.) under the intercropping patteren $(100 \%$ of the recommended seed rate of sugar beet $+30 \%$ of the recommended seed rate of wheat) produced the highest flag leaf area, in the first season. Whereas in the second one, only the nitrogen fertilization level (100 kg N/fed.) under the same intercropping patteren produced the highest flag leaf area.

The data presented in Table 2 revealed that the interaction between the interaction between intercropping patterens and bio-organic nitrogen fertilizers had a significant effect on flag leaf area, in both seasons. However, application of all bio-organic treatments under the intercropping patteren (100\% of the recommended seed rate of sugar beet $+30 \%$ of the recommended seed rate of wheat) recorded the highest values in the first season. On the other hand, application of mixture (Ser.+comp.) under the same intercropping patteren produced the highest flag leaf area, in the second season.

The interaction between mineral nitrogen fertilization levels and bio-organic nitrogen fertilizers in this study had a significant effect on flag leaf area in the first season only (Table 1). Application of mixture (Ser.+comp.) and application of compost only recorded the highest flag leaf area under the nitrogen fertilization level (100 kg N/fed.).

The effect of the second order interaction (intercropping patterens $\mathrm{x}$ mineral nitrogen fertilization levels $\mathrm{x}$ bioorganic nitrogen fertilizers) on that trait was significant in both seasons, Table 2, where application of mixture (Ser.+comp.) under the nitrogen fertilization level $(80 \mathrm{~kg} \mathrm{~N} / \mathrm{fed}$.) recorded the highest flag leaf area under the intercropping patteren ( $100 \%$ of the recommended seed rate of sugar beet $+30 \%$ of the recommended seed rate of wheat) in the first season. However, application of mixture (Ser.+comp.) under the nitrogen fertilization level (100 kg N/fed.) recorded the highest flag leaf area under the same intercropping patteren in the second season.

\section{B. Yield and yield components}

\section{B. A. Effect of intercropping patterens (P) \\ II. B. A.1. Number of spikes $/ \mathrm{m}^{2}$}

Number of spikes $/ \mathrm{m}^{2}$ as affected by intercropping patterns, between sugar beet and wheat in 2017/18 and 2018/19 seasons are presented in Table 1.

It is obvious that, intercropping patterns had a significant effect on no. of spikes $/ \mathrm{m}^{2}$ the highest numbers of spikes $/ \mathrm{m}^{2}$ were obtained by the third intercropping patteren $(100 \%$ of the recommended seed rate of sugar beet $+40 \%$ of the recommended seed rate of wheat) as compared with other intercropping patterens, this increases are mainly due the direct positive response to the increase in seeding rate which led to an increase in number of wheat plants per unit area. 
This result are in agree with those obtained by Attia et al., (2007), Ibrahim et al., (2008), Dina EL-Sherief (2013), Hala Shehata (2015) and Badr (2017). On contrast, the lowest values were detected by the first patteren (100\% of the recommended seed rate of sugar beet $+20 \%$ of the recommended seed rate of wheat).

However, solid wheat plants achieved the maximum number of spikes $/ \mathrm{m}^{2}$ as compared with intercropping patterens. These findings assured that dense sowing lead to a severe competition among plants for nutrients, water supply and light. So, plants grown crowded become less vigor than those grown wider

\section{B. A.2. Spike length (cm)}

Spike length of wheat plants wasn't significantly affected by intercropping patterns in both seasons, as shown in Table 1. No significant differences among intercropping patterens were detected in both seasons.

Dina EL-Sherief (2013), reported that, Planting pattern had no significant effect on spike length in the two seasons and no significant differences among intercropped wheat at 40,60 and $80 \mathrm{~cm}$ hill spaces were detected on spike length. In this connection, Badr (2017) found that no significant difference among wheat intercropped with sugar beet patterens on spike length.

\section{B. A. 3. Weight of spike (g)}

Results in Table 2 indicated that, spike weight of wheat was significantly influnced by intercropping patterens. The highest spike weight was obtained from the first intercropping patteren $(100 \%$ of the recommended seed rate of sugar beet $+20 \%$ of the recommended seed rate of wheat), while the third intercropping patteren (100\% of the recommended seed rate of sugar beet $+40 \%$ of the recommended seed rate of wheat) recorded the lowest weight of spike. Low density of intercropped wheat plants allowed to more light penetration within wheat canopy and turn in enhancing photosynthesis processand dry matter accumulation of spike weight as well as light sowing decreased intra specific competition among wheat plants compared with solid ones. Badr (2017) mentioned that, an increase in spike weight was observed under low denisity intercropped wheat plants with sugarbeet compared to high density intercropped wheat plants and pure stand plants.

\section{B. A.4. Number of grains/spike}

Intercropping patterens had a significant effect on number of grains/spike in both seasons. The highest no. of grains/spike was found by intercropping wheat at lowest seed rate. In another words, the first intercropping patteren ( $100 \%$ of the recommended seed rate of sugar beet $+20 \%$ of the recommended seed rate of wheat) scored the highest no. of grains/spike, whereas, the lowest number was recorded by the third intercropping patteren (100\% of the recommended seed rate of sugar beet $+40 \%$ of the recommended seed rate of wheat)

These finding assured that dense sowing lead to a serve competition among plants for nutrients, water supply and light. So, plants grown crowded become less vigor than those of thin sowing. Hence, a reduction in photosynthesis and metabolic processes for dense plants could be expected which would be reflected on fruiting organs size, grain filling, consequently, spike length, number of spikelets and grains/spike. Dina EL-Sherief (2013), showed that there was significantly reduction on number of grains/spike with increasing sowing denisity of intercropped wheat with sugar beet.

\section{B. A.5. 1000-grain weight (g)}

The results in Table 1 indicted that wheat plants recorded greater grain index at the lowest seed rate. The first intercropping patteren $(100 \%$ of the recommended seed rate of sugar beet $+20 \%$ of the recommended seed rate of wheat) recorded the highest 1000-grain weight with insignificant difference with the second intercropping patteren (100\% of the recommended seed rate of sugar beet $+30 \%$ of the recommended seed rate of wheat). On the other hand, the third intercropping patteren ( $100 \%$ of the recommended seed rate of sugar beet $+40 \%$ of the recommended seed rate of wheat) recorded the lowest 1000-grain weight, in both seasons. Generally, the intercropping patterens surpassed the solid wheat plants for trait in concern.

These increases indicated a greater grain filling and grain plumpness of wheat in intercropping due to better growth conditions and more light intensity with wheat canopy and high dry matter accumulation compared with wheat pure stand. Similar results were obtained by Abou - Elela(2012), Hala Shehata (2015) and Badr (2017) when they found that increasing wheat seed rate reduced 1000-grain weight.

\section{B. A.6. Grain yield (Ton/fed.)}

Grain yield of wheat which intercropped with sugar beet significantly increased with increasing seed rate from 20 up tn $40 \%$ of the recommended Table (27). The highest grain yield was detected by the third intercropping patteren ( $100 \%$ of the recommended seed rate of sugar beet $+40 \%$ of the recommended seed rate of wheat), followed by the second intercropping patteren $(100 \%$ of the recommended seed rate of sugar beet $+30 \%$ of the recommended seed rate of 
wheat), whereas the first intercropping patteren (100\% of the recommended seed rate of sugar beet $+20 \%$ of the recommended seed rate of wheat) ranked the last and produced the lowest grain yield/fed. However, solid wheat plants achieved the maximum grain yield compared with intercropping patterens.

The outstanding superiority of solid wheat mainly due to $100 \%$ occupied area with wheat and sowing with the recommended seed compared with less occupied area with wheat in case of intercropping patterns as well as less seeding rate. The results are quite expected and are in good agreement with those reported by Ibrahim et al., (2008), Abou-Elela (2012), Badr (2013), Dina EL-Sherief (2013), Hala Shehata (2015) and Badr (2017) they added that wheat yields/ fed. increased gradually by increasing wheat seeding rate when it intercropped with sugar beet.

\section{B. A.7. Straw yield (Ton/fed.)}

The trend of the trait in concern was similar to the trend of grain yield. Whereas, solid wheat plants achieved the maximum straw yield compared with intercropping patterens, this increase mainly due to the smaller area occupied with wheat in intercropping patterns. Also, straw yield of wheat which intercropped with sugar beet significantly increased with increasing seed rate from 20 up tn $40 \%$ of the recommended Table 2 . The highest straw yield was achieved by the third intercropping patteren $(100 \%$ of the recommended seed rate of sugar beet $+40 \%$ of the recommended seed rate of wheat), whereas the first intercropping patteren $(100 \%$ of the recommended seed rate of sugar beet $+20 \%$ of the recommended seed rate of wheat) ranked the last and produced the lowest straw yield/fed. These results were expected since straw yield positively corresponded with no. of tillers $/ \mathrm{m}^{2}$ and seed rate/fed. Similar results were obtained by Attia et al., (2007) and Abou - Elela (2012), Dina EL-Sherief (2013) and Badr (2017) where they mentioned that increasing wheat density increased straw yield/fed. of intercropped wheat with sugar beet

\section{B. A.8. Biological yield (Ton/fed.)}

The biological yield is the sum of grain and straw yields, and as the trend of these two traits was unified, the trend of the trait in concern was similar to this unified trend. Whereas, solid wheat plants achieved the maximum biological yield compared with intercropping patterens. Also, biological yield of wheat which intercropped with sugar beet significantly increased with increasing seed rate from 20 up tn $40 \%$ of the recommended Table (27). The highest biological yield was recorded by the third intercropping patteren $(100 \%$ of the recommended seed rate of sugar beet + $40 \%$ of the recommended seed rate of wheat), while the first intercropping patteren (100\% of the recommended seed rate of sugar beet $+20 \%$ of the recommended seed rate of wheat) ranked the last and produced the lowest biological yield/fed. This mainly attributed to heavy sowing resulting in high grain and straw yields. Dina EL-Sherief (2013) and Badr (2017) mentioned out that heavy sowing increaesed grain and straw yields and then achieved the highest biological yield among the intercropping patterens.

\section{B. A.9. Harvest index (\%)}

Harvest index of wheat as affected by intercropping patterens between sugar beet and wheat in 2017/18 and 2018/19 seasons are presented in Table ( ).

It's obvious from data that harvest index was affected significantly by intercropping patterns in the two seasons.

In the first season, the highest harvest index was detected by the third intercropping patteren (100\% of the recommended seed rate of sugar beet $+40 \%$ of the recommended seed rate of wheat), while in the second one the first intercropping patteren ( $100 \%$ of the recommended seed rate of sugar beet $+20 \%$ of the recommended seed rate of wheat) ranked the first grade. However the second intercropping patteren $(100 \%$ of the recommended seed rate of sugar beet + $30 \%$ of the recommended seed rate of wheat) ranked the last and recorded the lowest harvest index percentage in both seasons. Furthermore, the greatest harvest index was found in solid wheat with significant difference among other intercropping patterens of wheat in both seasons.

This trend of data may be due to the lowest straw yield recorded by the first intercropping patteren. These results are in agreement with those obtained by El- Ganayni and mahmoud, Gamalat (2008). On contrast, Dina ELSherief (2013), reported insignificant differences among planting patterns concerning to harvest index in the two seasons.

\section{B. B. Effect of Mineral nitrogen levels (N) \\ II. B. B.1. Number of spikes $/ \mathrm{m}^{2}$}

Results in Table 1 indicated that increasing nitrogen fertilizer levels increased significantly spike number of wheat $/ \mathrm{m}^{2}$ for both seasons. Rising nitrogen levels from 60 up to $100 \mathrm{Kg} \mathrm{N} /$ fed significantly increased number of spikes $/ \mathrm{m}^{2}$ and the highest number of spikes were obtained by using the highest nitrogen levels $100 \mathrm{~kg}$ N/fed., whereas, the lowest number of spikes were recorded by using the lowest nitrogen fertilizer level $60 \mathrm{~kg} N / \mathrm{fed}$. in both seasons, respectively. 
This positive relationship is a clear argument for the essential role of nitrogen for producing new tillers which led to the increase in number of tillers bearing fertile spikes. Results here accordance with those reported by Nadya Abdel Nour et al., (2011), Badr (2013), Amira EL-Mehy et al., (2016) and Badr (2017).

\section{B. B.2. Spike length (cm)}

Increase of nitrogen levels improved significantly spike length of wheat plants intercropped with sugarbeet in both seasons as shown in Table (27). Data indicated that, application of $100 \mathrm{~kg} \mathrm{~N} / \mathrm{fed}$. recorded the tallest spikes, while application of $60 \mathrm{~kg} \mathrm{~N} / \mathrm{fed}$. recorded the shortest spikes, in both seasons. This significant increment in spike length with increasing nitrogen fertilizer levels may be attributed to the role of nitrogen in promoting the growth of the plants, nutrient uptake, bio-chemical formation and different cell elongation and division resulted in long spike. These data was in the same line with those reported by Badr (2013), Amira EL-Mehy et al., (2016), Badr (2017) and Olga et al., (2019).

\section{B. B. 3. weight of spike (g)}

Weight of spikes (g) affected significantly by nitrogen levels. Increasing nitrogen levels from 60 up to $100 \mathrm{Kg}$ $\mathrm{N} /$ fed caused increase in weight of spikes $(\mathrm{g})$ as shown in Table 1 . The heaviest spikes were obtained from the highest $\mathrm{N}$ level $(100 \mathrm{Kg} \mathrm{N} / \mathrm{fed})$. On contrast, the lightest spikes were obtained from the lowest $\mathrm{N}$ level (60 Kg N/fed). This result may be indicate to active effect of nitrogen on metabolic process in wheat plants and this in turn stimulate their growth which might account for the superiority of spike weight. These results agreed with those obtaind by Badr (2013), and Amira EL-Mehy et al., (2016) and Badr (2017).

\section{B. B.4. Number of grains/spike}

Regarding to the effect of nitrogen levels on no. of grains/spike, data in Table 2, revealed that number of grains/spike affected significantly by increasing nitrogen fertilizer levels from 60 up to $100 \mathrm{Kg} N /$ fed. for intercropped wheat plants, in both seasons. Generally, increasing nitrogen fertilizer levels increased number of grains per spike. The highest number of grains/spikes was recorded by using the highest mineral nitrogen level (100 Kg N/fed.) and the lowest number was recorded by using the lowest level $(60 \mathrm{Kg} \mathrm{N} / \mathrm{fed}$.). The increases in number of grains/spike might be due to the role of nitrogen in encourging photosynthesis and other essential metabolic activities which affect positively on growth and development, availability of nutrition, which provided by higher rates of nitrogen fertilizer levels and also increase in spike length. These results are in agreement with those reported by Badr (2013), Amira EL-Mehy et al., (2016), Kandil et al., (2016), Badr (2017), Mattas et al., (2017) and Olga et al., (2019).

\section{B. B.5. 1000-grain weight (g)}

Data in Table 1 mentioned out that wheat yield character 1000-grain weight for intercropped wheat plants was affected significantly by nitrogen levels in both growing seasons. Raising nitrogen levels from 60 up to $100 \mathrm{Kg} \mathrm{N} / \mathrm{fed}$ caused a significant increase in 1000-grain weight $(\mathrm{g})$. The highest 1000 -grain weight was obtained with application of $100 \mathrm{Kg} \mathrm{N} / \mathrm{fed}$, whereas, the lowest weight was recorded by application of $60 \mathrm{Kg} \mathrm{N} / \mathrm{fed}$. Increase in 1000 -grain weight reflected the importance of nitrogen application as it is a necessary element for cell structure and function since protoplasm in the seat of cell division, photosynthetic, fruiting and grain development which lead to increasing dry matter accumulation resulted in heavy grains. In addition, increasing nitrogen levels improve the biotic process in plant and increasing the filling process in wheat grains. Similar trend of these results was reported by Badr (2013), Amira ELMehy et al., (2016), Badr (2017) and Maqsood et al., (2019).

\section{B. B.6. Grain yield (Ton/fed)}

With respect to the effect of nitrogen levels on grain yield (Ton/fed.), data in Table 1 indicated that grain yield was affected significantly by nitrogen levels. Increasing $\mathrm{N}$ level from 60 (Kg/fed.) to 80 (Kg/fed.) increased grain yield significantly. On the other hand, Increasing $\mathrm{N}$ level from 80 (Kg/fed.) to 100 (Kg/fed.) decreased slightly grain yield, while this shortage in grain yield under application of $100 \mathrm{~kg} \mathrm{~N} / \mathrm{fed}$. level didn't reach to the level of significance compared with grain yield under $80 \mathrm{~kg} \mathrm{~N} /$ fed. In another words, the lowest wheat grain yield for intercropped wheat plants was obtained under application of the lowest $\mathrm{N}$ level 60 (Kg/fed.), whereas, the highest wheat grain yield for intercropped wheat plants was obtained under application of the intermediate $\mathrm{N}$ level 80 (Kg/fed.) with insignificant differences with the grain yield recorded under application of the highest $\mathrm{N}$ level 100 (Kg/fed.). Many researchers observed same trend of these results such as Badr (2013), Amira EL-Meby et al., (2016) and Badr (2017).

\section{B. B.7. Straw yield (Ton/fed)}

Data in Table 1 indicated that the differences among nitrogen fertilizer levels were significant for straw yield in the two seasons. The highest $\mathrm{N}$ level $100 \mathrm{~kg} \mathrm{~N} / \mathrm{fed}$. produced the highest straw yield. Whereas, the lowest $\mathrm{N}$ level $60 \mathrm{~kg}$ $\mathrm{N} /$ fed. recorded the lowest straw yield, in both growing seasons. This positive relationship between straw yield/fed. and raising nitrogen fertilizer level refers to more vigor growth in plant height, flag leaf area and number of productive tillers and hence, increased straw yield/fed. These results are in agreement with those found by Badr (2013), Amira EL- Mehy et al., (2016), Badr (2017) and Olga et al., (2019). 


\section{B. B.8. Biological yield (Ton/fed):}

Data in Table 1 indicated that the differences among nitrogen fertilizer levels were significant for biological yield in the two seasons. The highest $\mathrm{N}$ level $100 \mathrm{~kg} \mathrm{~N} /$ fed. produced the highest biological yield. Whereas, the lowest $\mathrm{N}$ level $60 \mathrm{~kg} \mathrm{~N} /$ fed. recorded the lowest biological yield, in both growing seasons. This positive relationship between biological yield/fed. and raising nitrogen fertilizer level refers to increase in straw and grain yield which may be due to the increase in growth characters such as plant height and flag leaf area and some yield components traits such as number of tillers $/ \mathrm{m}^{2}$, number of spikes $/ \mathrm{m}^{2}$, spike length, weight of spike, Number of grains/spike,...etc. These results are in agreement with those found by Badr (2013), Amira EL- Mehy et al., (2016), Badr (2017) and Olga et al., (2019).

\section{B. B.9. Harvest index (\%)}

Data presented in Table 2, showed that, harvest index $(\%)$ differed significantly among nitrogen fertilizer levels in both seasons. The highest harvest index was recorded by the intermediate nitrogen fertilizer level $80 \mathrm{~kg} \mathrm{~N} / \mathrm{fed}$., with no significant difference with the lowest $\mathrm{N}$ level $60 \mathrm{~kg} \mathrm{~N} / \mathrm{fed}$. only in the first season. On the other hand, the lowest harvest index was scored by the highest $\mathrm{N}$ level $100 \mathrm{~kg} \mathrm{~N} / \mathrm{fed}$. in both seasons. This trend of data mainly attribute to that, the application of the highest $\mathrm{N}$ level $100 \mathrm{~kg} \mathrm{~N} / \mathrm{fed}$. surpassed significantly the intermediate nitrogen fertilizer level $80 \mathrm{~kg}$ $\mathrm{N} /$ fed. in straw yield/fed., whereas both $\mathrm{N}$ levels were at a par concerning to grain yield /fed. in both seasons. These results are in agreement with those obtained by Jamaati et al., (2018) and Olga et al., (2019).

\section{B. C. Effect of bio-organic nitrogen fertilizers (O) \\ II. B. C.1. Number of spikes $/ \mathrm{m}^{2}$.}

Number of spikes $/ \mathrm{m}^{2}$ as affected by bio-organic nitrogen fertilizers in 2017/18 and 2018/19 seasons are presented in Table 1. It is obvious that, the variations among application of serialine, compost and the mixture of both (Ser.+comp.) didn't reach to the level of significance in the first season, while in the second one the application of mixture (Ser.+comp.) and compost only produced the highest no. of spikes $/ \mathrm{m}^{2}$ and ranked the first, surpassing significantly application of serialine only. This trend of data may be due to the nitrogen availability caused by the mixed application of organic fertilization contains high percent of organic matter as a long term source of nitrogen side by side with $\mathrm{N}_{2}$ fixing bacteria in serialine biofertilizer. This positive effect of the mixture of bio-organic fertilizer is a clear argument for the essential role of nitrogen for producing new tillers which led to the increase in number of tillers bearing fertile spikes. Results here are in accordance with those reported by Mohammed et al., (2012) and Gomaa et al., (2015) where they reported a positive effect of adding organic fertilizer to wheat. Also, Rashwan et al., (2019), emphasized the positve role of $\mathrm{N}_{2}$ fixing bacteria in serialine on wheat growth.

\section{B. C.2. Spike length (cm)}

The application effect of the mixture of (Ser.+comp.) improved significantly spike length of wheat plants intercropped with sugarbeet in both seasons as shown in Table ( ). Data indicated that, application of the mixture of (Ser.+comp.) recorded the tallest spikes, while application of biofertilizer serialine only recorded the shortest spikes, in both seasons. This significant increment in spike length with the mixture of (Ser.+comp.) may be attributed to the role of compined effect of adding the organic matter to soil which enriches it with micro- and macro-elements side by side with seed inoculation with $\mathrm{N}_{2}$ fixing bacteria in serialine which produce growth promoting substances causing availability of nutrients and high nitrogen uptake by the inoculated plants. These data was in the same line with those reported by Mohammed et al., (2012), Gomaa et al., (2015) and Rashwan et al., (2019).

\section{B. C. 3. Weight of spike (g):}

Weight of spikes (g) affected significantly by bio-organic fertilizer. The application of the mixture of (Ser.+comp.) caused increase in weight of spikes (g) as shown in Table 1. In both seasons, the heaviest spikes were obtained from the mixture of (Ser.+comp.) with insignificant differences with the application of compost only in the first season. On contrast, the lightest spikes were obtained from application of serialine only. This result may be indicate to the combined effect of organic matter in supplies plants with micro- and macro-elements side by side with seed inoculation with $\mathrm{N}_{2}$ fixing bacteria in serialine which produce growth promoting substances causing availability of nutrients and high nitrogen uptake by the inoculated plants, which activates metabolic processes in wheat plants and this in turn stimulate their growth which might account for the superiority of spike weight. These results agreed with those obtaind by Gomaa et al., (2015), Rashwan et al., (2019) and Aleksandra et al., (2020).

\section{B. C.4. Number of grains/spike}

Regarding to the effect of bio-organicfertilizer on no. of grains/spike, data in Table 2, revealed that, the highest number of grains/spikes was recorded by using the mixture of (Ser.+comp.) which ranked the first, followed by using compost only, whereas the lowest number was recorded by using serialine only. 
The increases in number of grains/spike might be due to the availability of nitrogen, other macro and micro elements and growth supstances provided by serialine biofertilizer and compost which encourging photosynthesis and other essential metabolic activities which affect positively on growth and development. These results are in agreement with those reported by Gomaa et al., (2015), Rashwan et al., (2019) and Aleksandra et al., (2020).

\section{B. C.5. 1000-grain weight (g)}

Data in Table 1 mentioned out that wheat yield character 1000-grain weight for intercropped wheat plants was affected significantly by bio-organic fertilizer application in both growing seasons. The combined application of (Ser.+comp.) caused a significant increase in 1000-grain weight (g) compared to the single application of each one. In another words, the highest 1000-grain weight was obtained with application of the mixture (Ser.+comp.), whereas, the lowest weight was recorded by application of Serialine biofertilizer only. Increase in 1000-grain weight reflected the enhancement of cell structure and function since protoplasm in the seat of cell division, photosynthetic, fruiting and grain development which lead to increasing dry matter accumulation resulted in heavy grains as results for availability of nitrogen, other macro and micro elements and growth supstances provided by application of serialine biofertilizer and compost. Similar trend of these results was reported by Gomaa et al., (2015), Rashwan et al., (2019) and Aleksandra et al., (2020), where they reported a higher grain weight compared to the control as a result of bio-organic fertilizers.

\section{B. C.6. Grain yield (Ton/fed):}

Data in Table 1 indicated that the differences among application treatments (the mixture (Ser.+comp.), compost and serialine) were significant for grain yield in the two seasons. The combined application of (Ser.+comp.) produced the highest grain yield. Whereas, application of serialine biofertilization only recorded the lowest grain yield, in both growing seasons. This positive incerement of grain yield/fed. caused by the combined application of (Ser.+comp.) is an expected result with increase in growth characters such as plant height and flag leaf area from a side, and some yield components traits from the another side, such as number of tillers $/ \mathrm{m}^{2}$, number of spikes $/ \mathrm{m}^{2}$, spike length, weight of spike, Number of grains/spike.

These results are in agreement with those found by Mohammed et al., (2012), where they noted that, the interaction of $\mathrm{N}_{2}$ fixing bacteria with chicken manure as an organic fertilizer gave more significant grain yield increment. Furthermore, Gomaa et al., (2015), where they stated that application of organic fertilizer gave an increase in N, P and K content as compared with untreated treatment and the availability of these elements increased grain yield. Also, Rashwan et al., (2019) cleared that, wheat seed inoculation with $\mathrm{N}_{2}$-fixing bacteria increased grain yield as a result to the ability of $\mathrm{N}_{2}$ fixing bacteria to produce growth promoting substances and improving most of yield components traits. Moreover, Aleksandra et al., (2020), found that, application of exogenous organic matter (EOM) to soil acts as substitutes for synthetic nitrogen fertilizers and increase yield.

\section{B. C.7. Straw yield (Ton/fed)}

Data in Table 1 indicated that the differences among application treatments (the mixture (Ser.+comp.), compost and serialine) were significant for straw yield. In both seasons, the combined application of (Ser.+comp.) produced the highest straw yield with insignificant difference with the application of compost only in the first seasaon. Whereas, application of serialine biofertilization only recorded the lowest straw yield, in both growing seasons. the combined application of (Ser.+comp.) increased plant height, flag leaf area and number of tillers $/ \mathrm{m}^{2}$ as a result for abundance of nitrogen, other macro and micro elements and growth supstances provided by application of serialine biofertilizer and compost.

These results are in agreement with those found by Mohammed et al., (2012), where they noted that, the interaction of $\mathrm{N}_{2}$ fixing bacteria with chicken manure as an organic fertilizer gave more significant straw yield increment. Furthermore, Gomaa et al., (2015), where they stated that application of organic fertilizer gave an increase in N, P and K content as compared with untreated treatment and the availability of these elements increased straw yield. Also, Rashwan et al., (2019) cleared that, wheat seed inoculation with $\mathrm{N}_{2}$-fixing bacteria could partially replace about 10 mineral nitrogen units and increase straw yield as a result to the ability of $\mathrm{N}_{2}$ fixing bacteria to produce growth promoting substances and improving most of yield components traits. Moreover, Aleksandra et al., (2020), found that, application of exogenous organic matter (EOM) to soil acts as substitutes for synthetic nitrogen fertilizers and increase biomass.

\section{B. C.8. Biological yield (Ton/fed):}

Data in Table 1 indicated that the differences among application treatments (the mixture (Ser.+comp.), compost and serialine) were significant for biological yield in the two seasons. The combined application of (Ser.+comp.) produced the highest biological yield. Whereas, application of serialine biofertilization only recorded the lowest biological yield, in both growing seasons. This positive incerement of biological yield/fed. caused with the combined application of (Ser.+comp.) refers to increase in straw and grain yield which may be due to the increase in growth characters such as plant height and flag leaf area and some yield components traits such as number of tillers $/ \mathrm{m}^{2}$, number 
of spikes $/ \mathrm{m}^{2}$, spike length, weight of spike, Number of grains/spike,...etc. These results are in agreement with those found by Mohammed et al., (2012), where they noted that, the interaction of $\mathrm{N}_{2}$ fixing bacteria with chicken manure as an organic fertilizer gave more significant biomass increment. Furthermore, Gomaa et al., (2015), where they stated that application of organic fertilizer gave an increase in $\mathrm{N}, \mathrm{P}$ and $\mathrm{K}$ content as compared with untreated treatment and the availability of these elements increased biomass. Also, Rashwan et al., (2019) cleared that, wheat seed inoculation with $\mathrm{N}_{2}$-fixing bacteria increased growth traits and consequently the biomass as a result to the ability of $\mathrm{N}_{2}$ fixing bacteria to produce growth promoting substances. Moreover, Aleksandra et al., (2020), found that, application of exogenous organic matter (EOM) to soil acts as substitutes for synthetic nitrogen fertilizers and increase biomass.

\section{B. C.9. Harvest index (\%)}

Concerning to harvest index trait, the trend of data was similar to the trend of biological, grain and straw yield traits. Data presented in Table 2 showed that, harvest index (\%) differed significantly among application treatments (the mixture (Ser.+comp.), compost and serialine), in both seasons. The highest harvest index was recorded by the combined application of (Ser.+comp.). On the other hand, the lowest harvest index was scored by application of serialine biofertilization only, in both seasons. These results are in agreement with those obtained by Mohammed et al., (2012), Gomaa et al., (2015) and Rashwan et al., (2019).

\section{REFERENCES}

- Abd Alla, A. A., \& Omran, M. M. (2002). Response of some faba bean varieties to irrigation intervals and plant spacing in the new sandy reclaimed lands. Munufiya J. Agric. Res, 27, 525-540.

- Amany, M. A. (2014). Response of faba bean (Vicia faba L.) to different planting densities and bio-mineral fertilization systems. American-Eurasian Journal of Agricultural \& Environmental Sciences, 14(6), 541-545.

- Abd El-Zaher, S. R., \& Gendy, E. K. (2014). Effect of plant density and mineral and bio-nitrogen fertilization on intercropping faba bean with sugar beet. Egypt J Appl Sci, 29(7), 352-366.

- Idris, A. L. Y. (2008). Effect of seed size and plant spacing on yield and yield components of faba bean (Vicia faba L.). Research Journal of Agriculture and Biological Sciences, 4(2), 146-148.

- Abo Aisha A. K. E. (2020). Impact of planting methods and plant density for intercropped wheat on sugar beet productivity and quality of both crops. Ms. Thesis, Fac. of Agri. Saba Basha, Alexandria Univ.

- Abou Mostafa, R. A. I., El-Abbas, E., Rabie, E. M., \& Aboshady, K. A. (2012). Agronomic and economic evaluation for some patterns of intercropping faba bean with sugar beet under two sowing dates. Journal of Agricultural Research, Kafrelsheikh Univ, 38, 443-457.

- Abou-Amer, A. I., Fawy, H. A., \& Abdel Wahab, M. A. S. (2014). Effect of mineral fertilization and plant density on faba bean (Vicia faba) production in Siwa Oasis. Alex. J Agric Res, 59(1), 19 -26.

- Abou-Keriasha, M. A., Eisa, N. M., \& El-Wakil, N. M. H. (2013). Effects of intercropping faba bean on onion and wheat with or without inoculated bacteria on yields of the three crops. Egypt J Agron, 35(2), 169-182.

- $\quad$ Aboukhadra, S. H., Badawy, S. A., Toaima, S. E. A., \& El-Shireef, D. E. E. (2013). Effect of intercropping system of faba bean with sugar beet on their productivity and land use. Minufiya Journal of Agricultural Research, 38, 1501-1518.

- $\quad$ Aboukhadra, S. H., Badawy, S. A., Salah, E. A. T., \& El-Shireef, D. E. E. (2013). Effect of intercropping system of wheat with sugar beet on their productivity and land use. J of Agri Res, Kafr El-Sheikh Univ, 39, 37-54.

- Ali, H. A. O., \& El-Sheikh, K. A. A. (2008). Yield and its components in faba bean genotypes as influenced by cultivation method in reclaimed soil. Minia J. of Agric. Res. \& Develop, 28(1), 67-82.

- Gezahegn, A. M., Tesfaye, K., Sharma, J. J., \& Belel, M. D. (2016). Determination of optimum plant density for faba bean (Vicia faba L.) on vertisols at Haramaya, Eastern Ethiopia. Cogent Food \& Agriculture, 2(1), 1224485.

- Al-Rifaee, M. O. H. D., Turk, M. A., \& Tawaha, A. R. M. (2004). Effect of seed size and plant population density on yield and yield components of local faba bean (Vicia faba L. Major). International Journal of Agriculture and Biology, 6(2), 294-299.

- $\quad$ Naser, A. S., El-Hendawy, S., \& Schmidhalter, U. (2013). Influence Of Varied Plant Density On Growth, Yield And Economic Return Of Drip Irrigated Faba Bean. Turkish Journal of Field Crops, 18(2), 185-197.

- Anonymous. (2006). Recommendations techniques in field crops. ARC, Giza.

- Mitiku, A., \& Wolde, M. (2015). Effect of Faba Bean (Vicia faba L.) Varieties on Yield Attributes at Sinana and Agarfa Districts of Bale Zone, Southeastern Ethiopia. Jordan Journal of Biological Sciences, 8(4), 281-286.

- Badran, M. S. S., \& Ahmed, M. Z. D. (2010). Effect of sowing dates and planting methods on growth characters, seed yield and its components of faba bean in newly reclaimed lands. J. Agric. \& Env. Sci. Alex. Univ. Egypt, 9(1), 53-66.

- $\quad$ under Newly, S. F. B. V. (2011). Effect of row spacing on yield and its components of some faba bean varieties under newly reclaimed sandy soil condition. World Journal of Agricultural Sciences, 7(1), 68-72.

- Cossani, C. M., McMurray, L., Lake, L., \& Sadras, V. O. (2017). Impact of sowing date on phenology and yield of lentil and faba bean. Proceedings of the $18^{\text {th }}$ Australian Society of Agro. Conf, 24-28 Sept., Ballarat, Australia. 
(http:// www.agronomyaustraliaproceedings.org/)

- De Wit, C. T. (1960). Intercropping its importance and research needs. Part 1. Competition and yield advantages. Verslag Landbov Wkundige Onderz, 66, 1-82.

- El-Karamity, A. E., Abdullah, S. S., \& El-Ridwany, A. R. (2017). Effect of plant distribution and density on yield and yield components of some faba bean (Vicia faba L.) cultivars. Minia J Agric Res and Develop, 37(2), 211-230.

- Elshamy, M. A. (2016). Effect of faba bean sowing distance and some combinations of mineral nitrogen levels with bio-fertilizers on sugar beet and faba bean productivity under intercropping system. Egyptian Journal of Agronomy, 38(3), 489-507.

- $\quad$ FAOSTAT. (2018). Food and Agricultural Organization of The United Nation.

- Farghaly, B. S., Zohry, A. A., \& Bassal, S. A. A. (2003). Crops management for intercropping sugar beet with some essential crops to maximize area unit productivity. J. Agric. Sci. Mansoura Univ, 28(7), 5183-5199.

- Agegnehu, G., Ghizaw, A., \& Sinebo, W. (2006). Yield performance and land-use efficiency of barley and faba bean mixed cropping in Ethiopian highlands. European Journal of agronomy, 25(3), 202-207.

- Gomez, K. A., \& Gomez, A. A. (1984). Statiscal Procedures for Agricultural Research.2nd, (ed.). John Wiley and Sons, New York, U.S.A.

- Hegab, A. S. A., Fayed, M. T. B., Hamada, M. M., \& Abdrabbo, M. A. A. (2014). Productivity and irrigation requirements of faba-bean in North Delta of Egypt in relation to planting dates. Annals of Agricultural Sciences, 59(2), 185-193.

- Hussein, A. H. A., \& El-Deeb, M. A. (1999). Evaluation of intercropping faba bean, chickepea and lentil with sugar beet in Middle Egypt. Arab Universities Journal of Agricultural Sciences (Egypt). Arab Univ, J Agric Sci Ain Shams Univ, Cairo, 7(2), 475-482.

- Ibrahim, E. M., Badr, M. M. A., \& Abd El-Zaher, S. (2008, October). Response of some intercropping systems of wheat with sugar beet to bio-mineral nitrogenous fertilization. In Proceeding (The second field crop conference) FCRI, ARC, Giza, Egypt (pp. 435-451).

- M Ibrahim, H. (2016). Performance of some faba bean (Vicia faba L.) cultivars sown at different dates. Alexandria Science Exchange Journal, 37(April-June), 175-185.

- Ibrahim, M. E. M. (2018). Effect of preceding summer crops on yield and quality of sugar beet intercropped with faba bean. J Plant Production, Mansoura Univ, 9(1), 59-65.

- Ilkaee, M. N., Babaei, Z., Baghdadi, A., \& Golzardi, F. (2016). Effect of different planting dates and defoliation on the properties of sugar beet (Beta vulgaris L.). Journal of Experimental Biology and Agricultural Sciences, 4(1), 5258.

- Jackson, M. L. (1965) Soil Chemical Analysis. Constable Co, London.

- Badr, K. S. (2017). Integrated crop managements through optimal planting date and nitrogen fertilizer levels in wheat-sugar beet association on competitive relationships and yield advantages. Annals of Agricultural Science, Moshtohor, 55(3), 511-528.

- Khalil, N. A., Al-Murshidy, W. A., Eman, A. M., \& Badawy, R. A. (2015). Effect of plant density and calcium nutrition on growth and yield of some faba bean varieties under saline conditions. Agriculture and Food, 3, 440-450.

- Khalil, S. K., Wahab, A., Amanulla, A., \& Khan, A. Z. (2011). Variation in leaf traits, yield and yield components of faba bean in response to planting dates and densities. Egyptian Academic Journal of Biological Sciences, H. Botany, 2(1), 35-43.

- Khamooshi, H., Mohammadian, N., Saamdaliri, M., \& Foroughi, Z. (2015). Study on Effect of Plant Density and Nitrogen on Yield and Yield Components of Visia faba (Faba Bean). Journal of Ornamental Plants, 2(3), $161-167$.

- Lamani, K. D., \& Halikatti, S. I. (2019). Performance of Sugar Beet (Beeta vulgaris) to Different Dates of Sowing under Temperature Regime. International Journal of Plant \& Soil Science, 27(1), 1-12.

- Lemerle, D., Verbeek, B., \& Diffey, S. (2006). Influences of field pea (Pisum sativum) density on grain yield and competitiveness with annual ryegrass (Lolium rigidum) in south-eastern Australia. Australian Journal of Experimental Agriculture, 46(11), 1465-1472.

- Megawer, E. A., EL-Sherif, A. M. A., \& Mohamed, M. S. (2017). Performance of five Faba bean varieties under different irrigation intervals and sowing dates in newly reclaimed soil. Int. J. Agron. Agri, 57-66.

- El-Metwally, I. M., El-Shahawy, T. A., \& Ahmed, M. A. (2013). Effect of sowing dates and some broomrape control treatments on faba bean growth and yield. Journal of Applied Sciences Research, 9(1), 197-204.

- Mohammed, W. K., EA. El-Metwally, E., \& Saleh, S. A. (2005). Intercropping faba bean at different plant densities with sugar beet. Egyptian Journal of Agricultural Research, 83(2), 649-662.

- Moran, R., \& Porath, D. (1980). Chlorophyll determination in intact tissues using N, N-dimethylformamide. Plant physiology, 65(3), 478-479.

- Moursi, E. A., Nassr, M. M. I., \& EL-Mansoury, M. A. (2014). Effect Of Irrigation Intervals And Different Plant Densities On Faba Bean Yield, Some Water Relations And Some Soil Properties Under Drip Irrigation System In North Middle Nile Delta Region. Journal of Soil Sciences and Agricultural Engineering, 5(12), 1961-1716.

- Ntwana, B., \& Tuwana, S. W. (2013). Effect of planting date on yield and sugar content of sugar beet cultivars 
grown in Cradock, Eastern Cape. In African Crop Sci., Conf., Proc (Vol. 11, pp. 51-54).

- Rajcan, I., \& Swanton, C. J. (2001). Understanding maize-weed competition: resource competition, light quality and the whole plant. Field Crops Research, 71(2), 139-150.

- Saad, Sanaa, S. H. (2007). Effect of intercropping and nitrogenous fertilization on growth and yield of sugar beet. $\mathrm{Ph}$. D. Thesis, Fac, of Agric, Moshtohor (Benha Univ.) Egypt.

- Salama, H., El-Karamity, D. E. S., \& Nawar, A. I. (2016). Additive intercropping of wheat, barley, and faba bean with sugar beet: Impact on yield, quality and land use efficiency. Egyptian Journal of Agronomy, 38(3), 413-430.

- Sarmast, G. A. (2011). Effects of intensity and period of leaf area reduction at two dates of planting on phenology and yield of sugar beet. Ms.C. Thesis of Agriculture, Faculty of Agriculture, Islamic Azad University of Roodehen, Pp 121-123.

- $\quad$ Shaban, K. A., Khalil, A. A., \& Mohamed, A. A. (2013). Effect of sowing date and nitrogen, potassium fertilization on faba bean productivity in newly reclaimed saline soil of North Sinai. Journal of Soil Sciences and Agricultural Engineering, 4(9), 893-904.

- Shehata, H. (2015). Sowing sugar beet with wheat cultivars under different intercropping patterns. M. Sci., Thesis Fac. Of Agric, Minia Univ, Egypt.

- Singh, D., \& Choudhary, J. (2008). Effect of plant population and fertilizer levels on yield and economics of pop corn (Zea mays indurata). Indian Journal of Agricultural Sciences, 78(4), 370-371.

- Tamrat, W., Loha, G., \& Habte, A. (2019). Effect of Plant Density on Yield Components and Yield of Faba Bean (Vicia Faba L.) Varieties at Wolaita Sodo, Southern Ethiopia. J Natural Sci Res, 9(5), 47-55.

- Wakweya, K., Dargie, R., \& Meleta, T. (2016). Effect of sowing date and seed rate on faba bean (Vicia faba L.,) growth, yield and components of yield at Sinana, Highland conditions of Bale, Southeastern Ethiopia. International Journal of Scientific Research in Agricultural Sciences, 3(1), 25-34.

- Willey, R. (1979). Intercropping-its importance and research needs: Part 1. Competition and yield advantages. In Field crop abstracts, 32(1), 1-10.

- Winner, C. (1982). Zuckerrubenbau. DLG-Verlags-GmbH, Rusterstrasse 13, D-6000 Frankfurt am Main Germany. pp. 29.

- Ouda, S. A., \& Zohry, A. E. H. (2017). Crops intensification to reduce wheat gap in Egypt. In Future of food gaps in Egypt (pp. 37-56). Springer, Cham.

Citation: El-Seidy, E. H, A. M. Sheha, Ola A. Saleh, E. A. Rashwan (2021). Effect of Intercropping Wheat with Sugar Beet Patterens under Mineral Nitrogen and Bio-Organic Fertilization. South Asian Res J Agri Fish, 4(1), 7-13. 